ECAS expert consensus statement on catheter and surgical ablation of atrial fibrillation: recommendations for personnel, policy, procedures and follow-up. Heart Rhythm 2007; 4: 816-861

2) Haissaguerre $M$, Sanders $P$, Hocini $M$ et al: Changes in atrial fibrillation cycle length and inducibility during catheter ablation and their relation to outcome. Circulation 2004; 109: 3007-3013

3) Haissaguerre M, Sanders $P$, Hocini $M$ et al: Catheter ablation of long-lasting persistent atrial fibrillation: critical structures for termination. J Cardiovasc Electrophysiol 2005; 16: 1125-1137

4) Takahashi Y, O'Neill MD, Hocini M et al: Characterization of electrograms associated with termination of chronic atrial fibrillation by catheter ablation. J Am Coll Cardiol 2008; 51: 1003-1010

5) Takahashi $\mathrm{Y}$, O'Neill MD, Hocini $\mathrm{M}$ et al: Effects of stepwise ablation of chronic atrial fibrillation on atrial electrical and mechanical properties. J Am Coll Cardiol 2007; 49: 1306-1314

\title{
用圄圈説
}

\section{アンジオテンシン (1-7)}

アンジオテンシン II は 8 個のアミノ酸か らなるペプチドで, レニン・アンジオテンシ ン系において，もっとも強力な生理活性物質 であり，アンジオテンシン II 1 型 (AT1) 受 容体へ結合し，血管収縮・心肥大などを引き 起こす。アンジオテンシン (1-7) は, アン ジオテンシン・ワンツーセブンと呼ばれ，ア ンジオテンシン II の 8 番目のアミノ酸のな いペプチドとして発見され, 最近, その生理 作用が明らかとなってきた。

アンジオテンシン (1-7) は, 主にアンジ オテンシン変換酵素 2 (ACE2) によりアンジ オテンシン II が加水分解され産生されるも ので，心臓，腎臓，血管などに存在する。 そ して, Mas 受容体へ結合し，アンジオテン シン II とは相反する作用（血管拡張，利尿,
細胞増殖抑制作用など）を発揮する。また， 本態性高血压患者では，正常血圧者に比し尿 中アンジオテンシン (1-7) の排泄量が有意 に減少していることが報告されている．

さらに，動物実験ではあるが，心筋梗塞モ デルにAT1 受容体ブロッカー（ARB）を投 与すると，ACE2 の mRNA レベルと血墏ア ンジオテンシン (1-7) 濃度の上昇が観察さ れ，このペプチドが $\mathrm{ARB}$ の心保護作用の一 部を担っている可能性が示されている。 こ

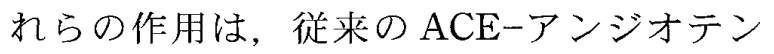
シン II-AT1 受容体（昇圧）系とは異なった ACE2-アンジオテンシン (1-7)-Mas 受容体 （降圧）系として注目されている.

(福岡大学医学部心臓・血管内科学 歹浦伸一郎，朔，啓二郎） 